\title{
Synthesis of Some New Spiro $\beta$-Lactams and Thiazolidinones Compounds Containing Sulfur Incorporating Quinon Compounds
}

\author{
Nadia Ali Ahmed El-Kanzi ${ }^{1,2}$ \\ ${ }^{1}$ Chemistry Department, Faculty of Science, Aswan University, Aswan, Egypt \\ ${ }^{2}$ Chemistry Department, Faculty of Science, Al-Jouf University, Sakaka, KSA \\ Email: nadiaelkanzi88@yahoo.com
}

Received October 11, 2012; revised November 17, 2012; accepted November 24, 2012

\begin{abstract}
A series of spiro, $\beta$-Lactams, and thiazolidinones incorporating compounds 4 have been synthesized by cycloaddition reaction of, chloroacetyl chloride and mercaptoacetic acid with the synthesized Shiff's bases 5a-c to give new spiro $\beta$ Lactam 6a-c and spiro thiazolidinone 7a-c the cycloaddition were characterized by spectral data including HNMR, ${ }^{13} \mathrm{C}-\mathrm{NMR}$, IR and elemental analysis.
\end{abstract}

Keywords: $\beta$-Lactam; Spiro Thiazolidinone; Synthesized; Cycloaddition

\section{Introduction}

$\beta$-Lactams, being a structural unit found in the most widely used antibiotics [1], have occupied a basic position in medicinal chemistry for almost a century now. With the microbes basic position in medicinal chemistry for almost a century now. With the microbes responding to the traditional antibiotics through $\beta$-lactamases, the need for novel antibiotics prevails, making synthesis of newer $\beta$-lactams ever more important. In addition to their use as antibiotics, $\beta$-lactams are increasingly being used as synthons for other biologically important molecules [2-11]. $\beta$-Lactams have been found to act as cholesterol acyl transferase inhibitors [12], thrombin inhibitors [13], human cytomegalovirus protease inhibitors [14], matrix metalloprotease inhibitors [15], cysteine protease [16], and apoptosis inductors [17]. Spirocyclic $\beta$-lactams have attracted attention as they have been shown to be $\beta$-turn mimetics $[18,19]$ and precursors for $\alpha, \alpha$-disubstituted $\beta$-amino acids [20]. The chartelline has a spiro- $\beta$-lactam moiety in its structure marine natural products [21]. It has been found that spiro- $\beta$-lactams act as poliovirus and human rhinovirus 3C-proteinases inhibitors [22]. These compounds are mostly synthesized by cycloaddition to an exocyclic bond. Several syntheses of spiro- $\beta$-lactams have been reported [23-42]. Polycyclic aromatic $\beta$-lactams have shown anticancer and other biological activities [43-45].

\section{Experimental}

\subsection{General}

Melting points are uncorrected. IR spectra were measured as $\mathrm{KBr}$ pelltes on a pye-unicam sp 1000 spectrophotometer. ${ }^{1} \mathrm{H}-\mathrm{NMR}$ spectra were recorded in $\left[{ }^{2} \mathrm{H}_{6}\right]$ dimethyl sulfoxide at $200 \mathrm{MHz}$ on a Varian Gemini NMR spectrometer using, MeSi as internal reference. Mass spectra were obtained on a shimadzu GCMS-QP 1000EX mass spectrometer at $70 \mathrm{eV}$. Elemental analysis was carried out at the Microanalytical Center of Cairo University.

\subsection{Synthesis of New 4,9-Diamino-2,3,7,8- tetramethyl-1,5a,6,10a-tetrahydropyrido [2,3-g]quinoline-5,10-dione1}

A solution of the appropriate acetamide $(0.59 \mathrm{~g}, 0.02$ mole) and malononitrile ( $0.66 \mathrm{~g}, 0.02$ mole) which prepared in situ in ethanol $(30 \mathrm{ml})$ containing $(0.5 \mathrm{ml})$ piperidine was treated with 1,4-p-benzoquinone $(0.02$ mole, $1.58 \mathrm{~g})$. The reaction mixture was heated under reflux for $13-15 \mathrm{~h}$ (monitored by TLC). The solvent was then evaporated under reduced pressure. Poured onto ice/ water acidified by $\mathrm{HCl}$, the solid product so formed was collected by filtration and crystallized from ethanol, yield $75 \%$; Mp: $295^{\circ} \mathrm{C}$; IR $\left(\mathrm{KBr}, \mathrm{Cm}^{-1}\right): v^{\sim} 3100-3400(\mathrm{NH}$, $\left.\mathrm{NH}_{2}\right), 2214(2 \mathrm{CN}), 1665(2 \mathrm{C}=\mathrm{O}) ;{ }^{1} \mathrm{H}-\mathrm{NMR} \delta(\mathrm{ppm})$ : 
1.63 (d. S, 6H, $2 \mathrm{CH}_{3}$ ), 6.01 (brs, $4 \mathrm{H}, 2 \mathrm{NH}_{2}$ ), $\delta 7.01-8.01$ (m, 2H, Ar-H), $\delta 9.67$ (brs, 2H, 2NH); ${ }^{13} \mathrm{C}-\mathrm{NMR} \delta$ (ppm): $174.09(\mathrm{C}=\mathrm{O}), 168.4(\mathrm{C}=\mathrm{O}), 152.5$ (carbon which attach by $\mathrm{CH}_{3}$ ), 119.4 (carbon which attach by $\mathrm{CN}$ ), 136.5 (carbon which attach by $\left.\mathrm{NH}_{2}\right) 98-135(\mathrm{C}=\mathrm{C}), 63(\mathrm{C}-\mathrm{N})$, $24\left(\mathrm{CH}_{3}\right), 117.3(\mathrm{CN})$; MS (334); analysis calculatedfor $\mathrm{C}_{17} \mathrm{H}_{14} \mathrm{O}_{2} \mathrm{~N}_{6}: \mathrm{C}, 61.0 ; \mathrm{H}, 4.22 ; \mathrm{N}, 25.22 \%$. Found: $\mathrm{C}$, $59.95 ; \mathrm{H}, 4.02 ; \mathrm{N}, 25.01 \%$.

\subsection{Synthesis of New 4,9-diamino-2,7-dimetyl- 5,10-dioxo-1,5,5a,6,10,10-ahexahydropyrido- [2,3-g]quinoline-3,8-dicarboxamide-2}

A mixture of compound 1 (3.34 g, 0.01 mole) and conc. Sulfuric acid $(20 \mathrm{ml})$ was stirred at room temperature. The reaction mixture was filtred and crystallized from ethanol to give compound 2 yield $73 \%$; Mp: $285^{\circ} \mathrm{C}$; IR $\left(\mathrm{KBr}, \mathrm{Cm}^{-1}\right): v^{\sim} 3150-3400\left(\mathrm{NH}, \mathrm{NH}_{2}\right), 1670(2 \mathrm{CO})$, 1645 (2CO); ${ }^{1} \mathrm{H}-\mathrm{NMR} \delta$ (ppm): $\delta 1.64$ (d. S, 6H, 2CH ), 6.49 (brs, $\left.4 \mathrm{H}, 2 \mathrm{NH}_{2}\right), \delta 7.01-8.01(\mathrm{~m}, 6 \mathrm{H}, \mathrm{Ar}-\mathrm{H}), \delta$ 10.50 (brs, 2H, 2NH). ${ }^{13} \mathrm{C}-\mathrm{NMR} \delta$ (ppm): $173.5(\mathrm{C}=\mathrm{O})$, $167.5(\mathrm{C}=\mathrm{O}), 165.5\left(\mathrm{C}=\mathrm{O}\right.$ which attach by $\left.\mathrm{NH}_{2}\right), 153.5$ (carbon which attach by $\mathrm{CH}_{3}$ ), 120.4 (carbon which attach by $\mathrm{CONH}_{2}$ ), 137 (carbon which attach by $\left.\mathrm{NH}_{2}\right) 98$ $135(\mathrm{C}=\mathrm{C}), 64(\mathrm{C}-\mathrm{N}), 23.5\left(\mathrm{CH}_{3}\right)$; MS (370); analysis calculated for: $\mathrm{C}_{17} \mathrm{H}_{18} \mathrm{O}_{4} \mathrm{~N}_{6}$ : C, 55.08; H, 4.89; N, 22.77\%. Found: C, 55.01; H, 4.93; N, 22.03\%.

\subsection{Synthesis of New Compound 4}

A mixture of compound 2 (3.70 g, 0.01 mole) and sulfur $(0.32 \mathrm{~g}, 0.01 \mathrm{~mole})$ in pyridine $30 \mathrm{ml}$ was refluxed for 15 h. The reaction mixture was filtred hot from the unreacted material, the filtrate was triturated with ice water acidified by conc. Hydrochloric acid the precipitate filtred, and crystallized from the proper solvent to give compound 4 Yield $76 \%$; $\mathrm{Mp}>300^{\circ} \mathrm{C}$; IR $\left(\mathrm{KBr}, \mathrm{Cm}^{-1}\right)$ : $v^{\sim} 3100-3400\left(\mathrm{NH}, \mathrm{NH}_{2}\right), 1670$ (2CO), $1645(2 \mathrm{CO}) ;{ }^{1} \mathrm{H}-$ NMR $\delta$ (ppm): $\delta 6.02$ (brs, $\left.4 \mathrm{H}, 2 \mathrm{NH}_{2}\right), \delta 7.01-8.01$ (m, $6 \mathrm{H}, \mathrm{Ar}-\mathrm{H}), \delta 9.51$ (brs, 2H, 2NH); ${ }^{13} \mathrm{C}-\mathrm{NMR} \delta$ (ppm): $173.5(\mathrm{C}=\mathrm{O}), 167.5(\mathrm{C}=\mathrm{O}), 164.5(\mathrm{C}=\mathrm{O}$ which attach by $\mathrm{NH}_{2}$ ), 120.4 (carbon which attach by $\mathrm{CONH}_{2}$ ), 137.5 (carbon which attach by $\left.\mathrm{NH}_{2}\right) 98-135(\mathrm{C}=\mathrm{C}), 63.5$ (C-N), $32\left(\mathrm{CH}_{2} \mathrm{~S}\right)$; MS (430); analysis calculated for: $\mathrm{C}_{17} \mathrm{H}_{14} \mathrm{O}_{4} \mathrm{~N}_{6} \mathrm{~S}_{2}$ : C, 47.44; H, 3.28; N, 19.52; S, 14.89\%. Found: C, 47.21; H, 3.36; N, 19.35; S, 14.81\%.

\subsection{Synthesis of New Schiff Bases 5a-c}

To a stirred solution of compound 4 (4.30 g, 0.01 mole) in a mixture of ethanol $(20 \mathrm{ml})$ and DMF $(10 \mathrm{ml})$, different aromatic amine $(2.22 \mathrm{~g}, 0.02$ mole; $2.44 \mathrm{~g}, 0.02$ mole; $3.02 \mathrm{~g}, 0.02$ mole) respectively in presence of $(0.5$ $\mathrm{ml}$ ) piperidine catalyst. The reaction mixture was heated under reflux for $9 \mathrm{~h}$. The reaction mixture diluted with ice water and neutralized with hydrochloric acid. The solid product formed on standing over night was filtred, washed thoroughly with cold water, and dried, recrystallization from dimethylformamide to give 5a-c.

5a: yield $70 \% ; \mathrm{Mp}>300^{\circ} \mathrm{C}$; IR $\left(\mathrm{KBr}, \mathrm{Cm}^{-1}\right) v^{\sim}: 3100$ - $3400\left(\mathrm{NH}, \mathrm{NH}_{2}\right), 1680(2 \mathrm{CO}), 1586(\mathrm{C}=\mathrm{N})$; ${ }^{1} \mathrm{H}-\mathrm{NMR} \delta$ (ppm): 6.69 (brs, 4H, 2NH $), \delta 7.01-8.01(\mathrm{~m}, 16 \mathrm{H}$, Ar-H), $\delta 10.46$ (brs, 2H, 2NH), $\delta 11.42$ (brs, 2H, 2NH); MS (612); analysis calculated for: $\mathrm{C}_{29} \mathrm{H}_{24} \mathrm{O}_{4} \mathrm{~N}_{8} \mathrm{~S}_{2}$ : C, 56.85; H, 3.95; N, 18.29; S, 10.46\%. Found: C, 56.80; H, $3.69 ; \mathrm{N}, 18.01 ; \mathrm{S}, 10.25 \%$.

5b: yield $72 \%$; $\mathrm{Mp}>300^{\circ} \mathrm{C}$; IR $\left(\mathrm{KBr}, \mathrm{Cm}^{-1}\right) v^{\sim}: 3100$ - $3400\left(\mathrm{NH}, \mathrm{NH}_{2}, \mathrm{OH}\right), 1687$ (2CO), $1590(\mathrm{C}=\mathrm{N})$; ${ }^{1} \mathrm{H}-$

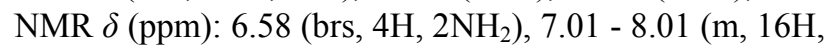
Ar-H), $\delta 10.38$ (brs, 2H, 2NH), $\delta 11.26$ (brs, 2H, 2NH); MS (644); analysis calculated for: $\mathrm{C}_{29} \mathrm{H}_{24} \mathrm{O}_{6} \mathrm{~N}_{8} \mathrm{~S}_{2}$ : C, 54.03; H, 3.76; N, 17.38; S, 9.95\%. Found: C, 53.99; H, $3.37 ; \mathrm{N}, 17.26 ; \mathrm{S}, 9.24 \%$.

5c: yield $75 \% ; \mathrm{Mp}>300^{\circ} \mathrm{C}$; IR $\left(\mathrm{KBr}, \mathrm{Cm}^{-1}\right) v^{\sim}: 3100$ $3400\left(\mathrm{NH}, \mathrm{NH}_{2}\right), 1690(2 \mathrm{CO}), 1593(\mathrm{C}=\mathrm{N}) ;{ }^{1} \mathrm{H}-\mathrm{NMR} \delta$ (ppm): 6.71 (brs, 4H, 2NH 2$), 7.01-8.01$ (m, 14H, Ar-H), $\delta 10.51$ (brs, 2H, 2NH), $\delta 11.46$ (brs, 2H, 2NH); MS (702); analysis calculated for: $\mathrm{C}_{29} \mathrm{H}_{22} \mathrm{O}_{8} \mathrm{~N}_{10} \mathrm{~S}_{2}$ : C, 49.57; H, 3.16; N, 19.93; S, 9.13\%. Found: C, 49.52; H, 3.02; N, $19.27 ; \mathrm{S}, 9.01 \%$.

\subsection{Synthesis of New $\beta$-Lactam 6a-c}

A mixture of $5 \mathrm{a}-\mathrm{c}(6.12 \mathrm{~g}, 6.44 \mathrm{~g}, 7.02 \mathrm{~g}, 0.01 \mathrm{~mol}) \mathrm{re}-$ spectively and chloroacetyl chloride (1.13 g, 0.02 mole) in a mixture of ethanol $(20 \mathrm{ml})$ and DMF $(10 \mathrm{ml})$ in the presence of $(0.5 \mathrm{ml})$ of triethylamine was refluxed for 15 h. After removal the solvent under reduced pressure, the resulting solid product was filtred and washed with water. The crude product was recrystallized from dimethylformamide and ethanol to yield the corresponding 6a-c.

6a: yield $67 \% ; \mathrm{Mp}>300^{\circ} \mathrm{C}$; $\mathrm{IR}\left(\mathrm{KBr}, \mathrm{Cm}^{-1}\right) v^{\sim}: 3100$ - 3400 (NH, NH2), 1750 (2CO Of $\beta$ lactam), 1657 (2CO); ${ }^{1} \mathrm{H}-\mathrm{NMR} \delta$ (ppm): 6.55 (brs, 4H, 2NH ), $\delta 7.01$ - 8.01 (m, $18 \mathrm{H}, \mathrm{Ar}-\mathrm{H}$ ), $\delta 10.39$ (brs, 2H, 2NH), 11.44 (brs, 2H, $2 \mathrm{NH}) ;{ }^{13} \mathrm{C}-\mathrm{NMR} \delta(\mathrm{ppm})$ : Aromatic carbon 114 - 157, 163.5 (CO of $\beta$ lactam); MS (765); analysis calculated for: $\mathrm{C}_{33} \mathrm{H}_{26} \mathrm{O}_{6} \mathrm{~N}_{8} \mathrm{Cl}_{2} \mathrm{~S}_{2}$ : C, 51.77; H, 3.42; N, 14.63; S, 8.37; Cl, 9.26\%. Found: C, 51.59; H, 3.39; N, 14.28; S, $8.19 ; \mathrm{Cl}, 9.15 \%$.

6b: yield $65 \%$; $\mathrm{Mp}>300^{\circ} \mathrm{C}$; IR $\left(\mathrm{KBr}, \mathrm{Cm}^{-1}\right) v^{\sim}: 3150$ - 3400 (NH, $\left.\mathrm{NH}_{2}, \mathrm{OH}\right), 1755$ (2CO Of $\beta$ lactam), 1650 (2CO); ${ }^{1} \mathrm{H}-\mathrm{NMR} \delta$ (ppm): 6.53 (brs, $\left.4 \mathrm{H}, 2 \mathrm{NH}_{2}\right), \delta 7.01$ $8.01(\mathrm{~m}, 18 \mathrm{H}, \mathrm{Ar}-\mathrm{H}), \delta 10.29$ (brs, 2H, 2NH), 11.41 (brs, $2 \mathrm{H}, 2 \mathrm{NH}) ;{ }^{13} \mathrm{C}-\mathrm{NMR} \delta$ (ppm): 114.5 - 158 (aromatic carbon), 165 (CO of $\beta$ lactam); MS (797); analysis calculated for: $\mathrm{C}_{33} \mathrm{H}_{26} \mathrm{O}_{8} \mathrm{~N}_{8} \mathrm{Cl}_{2} \mathrm{~S}_{2}: \mathrm{C}, 49.69 ; \mathrm{H}, 3.29 ; \mathrm{N}$, 14.05; S, 8.04; Cl, 8.89\%. Found: C, 49.45; H, 3.16; N, 13.96; S, 7.97; Cl, 8.74\%. 
6c: yield $69 \%$; $\mathrm{Mp}>300^{\circ} \mathrm{C}$; IR $\left(\mathrm{KBr}, \mathrm{Cm}^{-1}\right) v^{\sim}: 3100$ $3400\left(\mathrm{NH}, \mathrm{NH}_{2}\right), 1758$ (2CO Of $\beta$ lactam), 1660 (2CO); ${ }^{1} \mathrm{H}-\mathrm{NMR} \delta(\mathrm{ppm}): 6.60$ (brs, $\left.4 \mathrm{H}, 2 \mathrm{NH}_{2}\right), \delta 7.01-8.01(\mathrm{~m}$, $16 \mathrm{H}, \mathrm{Ar}-\mathrm{H}$ ), $\delta 10.43$ (brs, 2H, 2NH), 11.50 (brs, 2H, $2 \mathrm{NH}) ;{ }^{13} \mathrm{C}-\mathrm{NMR} \delta(\mathrm{ppm}): 115$ - 158.5 (aromatic carbon) 165.5 (CO of $\beta$ lactam); MS (855); analysis calculated for: $\mathrm{C}_{33} \mathrm{H}_{24} \mathrm{O}_{10} \mathrm{~N}_{10} \mathrm{Cl}_{2} \mathrm{~S}_{2}$ : C, 46.32; $\mathrm{H}, 2.83 ; \mathrm{N}, 16.37 ; \mathrm{S}$, 7.49 ; Cl, 8.29\%. Found: C, 46.04; H, 2.62; N, 16.26; S, $7.37 ; \mathrm{Cl}, 8.13 \%$.

\subsection{Synthesis of New Thiazolidinone 7a-c}

A mixture of $5 \mathrm{a}-\mathrm{c}(6.12 \mathrm{~g}, 6.44 \mathrm{~g}, 7.02 \mathrm{~g}, 0.01 \mathrm{~mole})$ respectively and mercaptoacetic acid $(0.92 \mathrm{~g}, 0.02$ mole) was refluxed in a mixture of ethanol $(20 \mathrm{ml})$ and DMF $(10 \mathrm{ml})$ in the presence of $(0.5 \mathrm{ml})$ of triethylamine was refluxed for $16 \mathrm{~h}$. The resulting residue was triturated with ice water neutralized by concentrated hydrochloric acid and was allowed to stand over night. The solid thus obtained washed with water, dried, and recrystallized from ethanol to yield the corresponding $7 \mathrm{a}-\mathrm{c}$.

7a: yield $68 \%$; $\mathrm{Mp}>300^{\circ} \mathrm{C}$; IR $\left(\mathrm{KBr}, \mathrm{Cm}^{-1}\right)$ v: 3100 - $3400\left(\mathrm{NH}, \mathrm{NH}_{2}\right), 1700$ (2CO), 1655 (2CO); ${ }^{1} \mathrm{H}-\mathrm{NMR} \delta$ (ppm): 2.51 (d. S, $4 \mathrm{H}, 2 \mathrm{CH}_{2}$ of thiazolodinone) $\delta 6.65$ (brs, $\left.4 \mathrm{H}, 2 \mathrm{NH}_{2}\right), \delta 7.01-8.01(\mathrm{~m}, 16 \mathrm{H}, \mathrm{Ar}-\mathrm{H}), \delta 10.47$ (brs, 2H, 2NH), 11.35 (brs, 2H, 2NH); MS (760); analysis calculated for: $\mathrm{C}_{33} \mathrm{H}_{28} \mathrm{O}_{6} \mathrm{~N}_{8} \mathrm{~S}_{4} ; \mathrm{C}, 52.09 ; \mathrm{H}, 3.71 ; \mathrm{N}$, 14.73 ; S, 16.85\%. Found: C, 52.01; H, 3.74; N, 14.45; S, $16.65 \%$.

7b: yield $65 \%$; $\mathrm{Mp}>300^{\circ} \mathrm{C}$; IR $\left(\mathrm{KBr}, \mathrm{Cm}^{-1}\right) v^{\sim}: 3100$ - $3400\left(\mathrm{NH}, \mathrm{NH}_{2}, \mathrm{OH}\right), 1692$ (2CO), $1650(2 \mathrm{CO}) ;{ }^{1} \mathrm{H}-$ NMR $\delta$ (ppm): 2.50 (d. S, $4 \mathrm{H}, 2 \mathrm{CH}_{2}$ of thiazolidinone), $\delta$ 6.62 (brs, $\left.4 \mathrm{H}, 2 \mathrm{NH}_{2}\right), \delta 7.01-8.01(\mathrm{~m}, 16 \mathrm{H}, \mathrm{Ar}-\mathrm{H}), \delta$ 10.38 (brs, 2H, 2NH), 11.27 (brs, 2H, 2NH); MS (792); analysis calculated for: $\mathrm{C}_{33} \mathrm{H}_{28} \mathrm{O}_{8} \mathrm{~N}_{8} \mathrm{~S}_{4} ; \mathrm{C}, 49.99 ; \mathrm{H}, 3.56$; N, 14.13; S, 16.17\%. Found: C, 49.86; H, 3.37; N, 14.03; $\mathrm{S}, 16.01 \%$.

7c: yield $63 \%$; $\mathrm{Mp}>300^{\circ} \mathrm{C}$; IR $\left(\mathrm{KBr}, \mathrm{Cm}^{-1}\right) v^{\sim}: 3150$ $3400\left(\mathrm{NH}, \mathrm{NH}_{2}, \mathrm{OH}\right), 1705(2 \mathrm{CO}), 1660(2 \mathrm{CO}) ;{ }^{1} \mathrm{H}-$ NMR $\delta$ (ppm): 2.52 (d. S, $4 \mathrm{H}, 2 \mathrm{CH}_{2}$ of thiazolidinone), $\delta$ 6.69 (brs, $\left.4 \mathrm{H}, 2 \mathrm{NH}_{2}\right), \delta 7.01-8.01(\mathrm{~m}, 14 \mathrm{H}, \mathrm{Ar}-\mathrm{H}), \delta$ 10.51 (brs, 2H, 2NH), 11.39 (brs, 2H, 2NH); MS (850); analysis calculated for: $\mathrm{C}_{33} \mathrm{H}_{26} \mathrm{O}_{10} \mathrm{~N}_{10} \mathrm{~S}_{4}: \mathrm{C}, 46.58 ; \mathrm{H}$, 3.08 ; N, 16.46; S, 15.07\%. Found: C, 46.39; H, 3.02; N, $16.28 ; \mathrm{S}, 14.99 \%$.

\section{Result and Discussion}

\subsection{Synthesis}

Our initial strategy in this research project for the synthesis of different structural formulas corresponding spiro systems depended upon the synthesis of the new fused compound 1, which was synthesized by a cycloaddition reaction of equimolecular ratios of the appropriate acetamide and malononitrile with 2 mole of $p$-benzoquinone (one mole used as an oxidizing agent), in ethanol containing piperidine as catalyst [46]. The cycloaddition reaction leads to the formation of compound 1 through the electronic cyclization according to the suggested mechanism (Scheme 1).

The structure of the new synthesized compound 1 IR spectra which revealed a two carbonyl groups at 1665 $\mathrm{cm}^{-1}$, two cyano group at $2214 \mathrm{~cm}^{-1}$ and ${ }^{1} \mathrm{H}-\mathrm{NMR}$ spectra, which revealed the presence of two NH groups at $\delta$ 9.67, two $\mathrm{NH}_{2}$ groups at $\delta 6.01$, doublet singlet at 1.63 assigned for two methyl group. The mass spectrum showed the molecular ion peak $\left(\mathrm{M}^{+}, \mathrm{C}_{17} \mathrm{H}_{14} \mathrm{O}_{2} \mathrm{~N}_{5}\right)$ at $\mathrm{m} / \mathrm{z}$ 334. ${ }^{13} \mathrm{C}$-NMR $\delta(\mathrm{ppm}): 174.09(\mathrm{C}=\mathrm{O}), 168.4(\mathrm{C}=\mathrm{O})$, 152.5 (carbon which attach by $\mathrm{CH}_{3}$ ), 119.4 (carbon which attach by $\mathrm{CN}$ ), 136.5 (carbon which attach by $\mathrm{NH}_{2}$ ) $98-135(\mathrm{C}=\mathrm{C}), 63(\mathrm{C}-\mathrm{N}), 24\left(\mathrm{CH}_{3}\right), 117.3(\mathrm{CN})$.

When a mixture of compound 1 and conc. Sulfuric acid was stirred at room temperature, hydrolysis of the cyano group took place to give compound 2 . The structure of the new synthesized compound 2 was confirmed by its elemental analysis and IR spectra which revealed a carbonyl group at $1645 \mathrm{~cm}^{-1}$ and two carbonyl group at $1665.5 \mathrm{~cm}^{-1}$ and the ${ }^{1} \mathrm{H}-\mathrm{NMR}$ spectra, which revealed the presence of two $\mathrm{NH}$ groups at $\delta 10.50$, two $\mathrm{NH}_{2}$ group at $\delta 6.49$ doublet, singlet at $\delta 1.64$ assigned for two methyl group. The mass spectrum showed the molecular ion peak $\left(\mathrm{M}^{+}, \mathrm{C}_{17} \mathrm{H}_{18} \mathrm{O}_{4} \mathrm{~N}_{6}\right)$ at $\mathrm{m} / \mathrm{z} 370 .{ }^{13} \mathrm{C}$-NMR $\delta$ (ppm): $173.5(\mathrm{C}=\mathrm{O}), 167.5(\mathrm{C}=\mathrm{O}), 165.5(\mathrm{C}=\mathrm{O}$ which attach by $\mathrm{NH}_{2}$ ), 153.5 (carbon which attach by $\mathrm{CH}_{3}$ ), 120.4 (carbon which attach by $\mathrm{CONH}_{2}$ ), 137 (carbon which attach by $\left.\mathrm{NH}_{2}\right) 98-135(\mathrm{C}=\mathrm{C}), 64(\mathrm{C}-\mathrm{N}), 23.5$ $\left(\mathrm{CH}_{3}\right)$. The intelligible bases of IR spectra led us to decide that the isolable structural formula produced from the reaction of compound 2 with sulfuric acid is the structural formula of compound 2 because the absence of peak at 2214 assigned for the cyano group. On the other hand, compound 2 was reacted with sulfur in pyridine which refluxed for $19 \mathrm{~h}$ to give new compound 4 . The structure of the new synthesized compound 4 was confirmed by its elemental analysis and IR spectra which revealed the presence of two carbonyl group of quinone at $1675 \mathrm{~cm}^{-1}$ and two carbonyl group at $1640 \mathrm{~cm}^{-1}$. The ${ }^{1} \mathrm{H}-\mathrm{NMR}$ spectra revealed the presence of (brs, $2 \mathrm{H}, 2 \mathrm{NH}$ ) at $\delta 9.51$ and (brs, $2 \mathrm{H}, 2 \mathrm{NH}$ ) at $\delta 10.67$, (brs, $4 \mathrm{H}, 2 \mathrm{NH}_{2}$ ) at $\delta 6.02$ the absence of doublet singlet at $\delta 1.64$ led us to decide that the structural formula of compound 4 . The mass spectra showed the molecular ion peak $\left(\mathrm{M}^{+}\right.$, $\left.\mathrm{C}_{17} \mathrm{H}_{14} \mathrm{O}_{4} \mathrm{~N}_{6} \mathrm{~S}_{2}\right)$ at $\mathrm{m} / \mathrm{z} 430$. and ${ }^{13} \mathrm{C}-\mathrm{NMR} \delta(\mathrm{ppm}): 173.5$ $(\mathrm{C}=\mathrm{O}), 167.5(\mathrm{C}=\mathrm{O}), 164.5\left(\mathrm{C}=\mathrm{O}\right.$ which attach by $\left.\mathrm{NH}_{2}\right)$, 120.4 (carbon which attach by $\mathrm{CONH}_{2}$ ), 137.5 (carbon which attach by $\left.\mathrm{NH}_{2}\right) 98-135(\mathrm{C}=\mathrm{C}), 63.5(\mathrm{C}-\mathrm{N}), 32$ $\left(\mathrm{CH}_{2} \mathrm{~S}\right)$. 


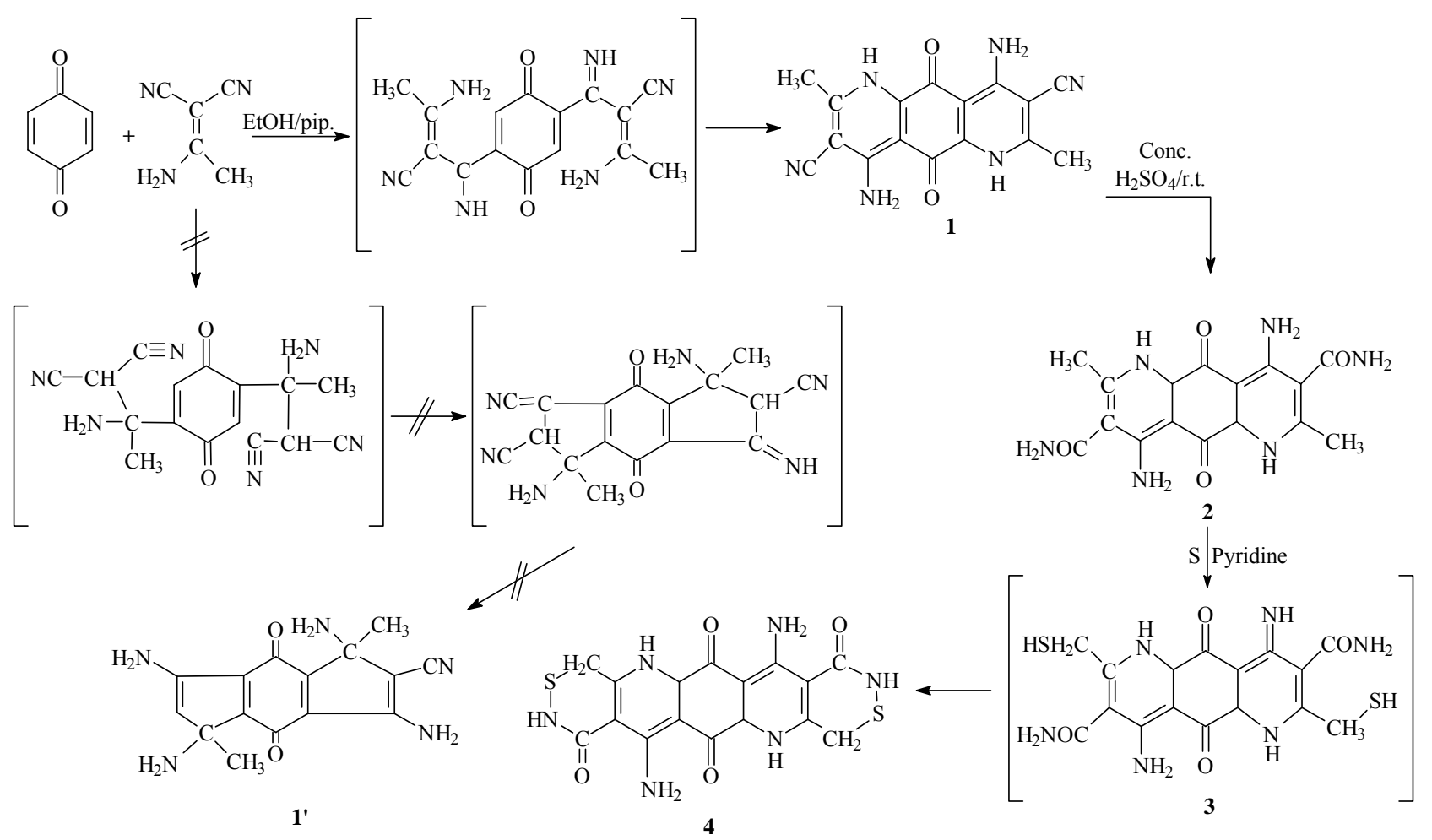

Scheme 1. Illustrate the formation of compound 1, 2 and 4.

It is very important to know that the formation of Schiff bases corresponding to the newly heterocyclic compounds is the cornerstone in the synthesis of the corresponding spiro $\beta$-Lactams and thiazolidinone compounds. The activity of the two carbonyl group in compound 4 render compound 4 to react with different aromatic amine in the presence of a mixture of ethanol (20 $\mathrm{ml})$ and DMF $(10 \mathrm{ml})$ as solvent at $(0.5 \mathrm{ml})$ piperidine catalyst to give new Schiff bases 5a-c. The structure of these newly synthesized Schiff base was confirmed by their elemental analysis, IR, ${ }^{1} \mathrm{H}-\mathrm{NMR}$ and mass spectra. The activity of azamethine centre in compound 5a-c is more available than the activity of the $\mathrm{NH}$ group toward the addition process of chloroacetyl chloride, and this mentioned phenomena is due to the presence of the $\pi$ electron, which makes the foundation of the $\delta$ positive and $\delta$ negative charge on the carbon and nitrogen atom, respectively, more easy than the presence of this phenomena on the $\mathrm{NH}$ group in which the bonding between nitrogen and hydrogen wheather strong according to the nature of this bonding which leads to decreasing of the mobility desire of the hydrogen atom of this $\mathrm{NH}$ group [46]. Thus compound 5a-c reacted with chloroacetyl chloride or mercaptoacetic acid [47] to give spiro $\beta$ Lactams and spiro thiazolidinone compounds $6 \mathrm{a}-\mathrm{c}$ and 7a-c (Scheme 2). The structures of these spiro compounds $6 \mathrm{a}-\mathrm{c}$ and $7 \mathrm{a}-\mathrm{c}$ were confirmed by their elemental analysis, IR, ${ }^{1} \mathrm{H}-\mathrm{NMR}$, mass spectra and ${ }^{13} \mathrm{C}-\mathrm{NMR}$.

\section{2. ${ }^{1} \mathrm{HNMR}$ and IR}

Figure 1 illustrates ${ }^{1} \mathrm{HNMR}$ spectra of compound 1 which revealed the presence of two NH groups at $\delta 9.67$, two $\mathrm{NH}_{2}$ groups at $\delta 6.01$, doublet singlet at 1.63 assigned for two methyl group.

Also, Figure 2 indicates ${ }^{1}$ HNMR spectra of compound 2 revealed the presence of $\delta 1.64\left(\mathrm{~d} . \mathrm{S}, 6 \mathrm{H}, 2 \mathrm{CH}_{3}\right), 6.49$ (brs, $\left.4 \mathrm{H}, 2 \mathrm{NH}_{2}\right), \delta 7.01-8.01(\mathrm{~m}, 6 \mathrm{H}, \mathrm{Ar}-\mathrm{H}), \delta 10.50$ (brs, $2 \mathrm{H}, 2 \mathrm{NH}$ ). Figure 3 indicates ${ }^{1} \mathrm{HNMR}$ spectra of compound 4 which revealed the absence of absorbtion of two methyl groups; ${ }^{1} \mathrm{H}-\mathrm{NMR} \delta$ (ppm): $\delta 6.02$ (brs, $4 \mathrm{H}$, $\left.2 \mathrm{NH}_{2}\right), \delta 7.01-8.01(\mathrm{~m}, 6 \mathrm{H}, \mathrm{Ar}-\mathrm{H}), \delta 9.51$ (brs, $2 \mathrm{H}$, $2 \mathrm{NH})$.

Figure 4 indicates IR spectra of compound 1:IR(KBr, $\left.\mathrm{Cm}^{-1}\right): v^{\sim} 3100-3400\left(\mathrm{NH}, \mathrm{NH}_{2}\right), 2214(2 \mathrm{CN}), 1665$ $(2 \mathrm{C}=\mathrm{O})$, which reveald the presence of two cyano groups at $2216 \mathrm{Cm}^{-1}$ while Figure 5 shows IR spectra of compound 2 which indicate the absence of two cyano groups due to hydrolysis process, Figure 6 shows IR spectra of compound 4 as follow, IR $\left(\mathrm{KBr}, \mathrm{Cm}^{-1}\right): v^{\sim} 3100-3400$ $\left(\mathrm{NH}, \mathrm{NH}_{2}\right), 1670$ (2CO), 1645 (2CO).

\section{Conclusion}

New $\beta$-lactams 6a-c and new thiazolidinone 7a-c were obtained by reaction of compound 4 with different aromatic amine to give new shiff's basess $5 \mathrm{a}-\mathrm{c}$ which react with chloroacetyle chloride and or mercaptoacetic acid 


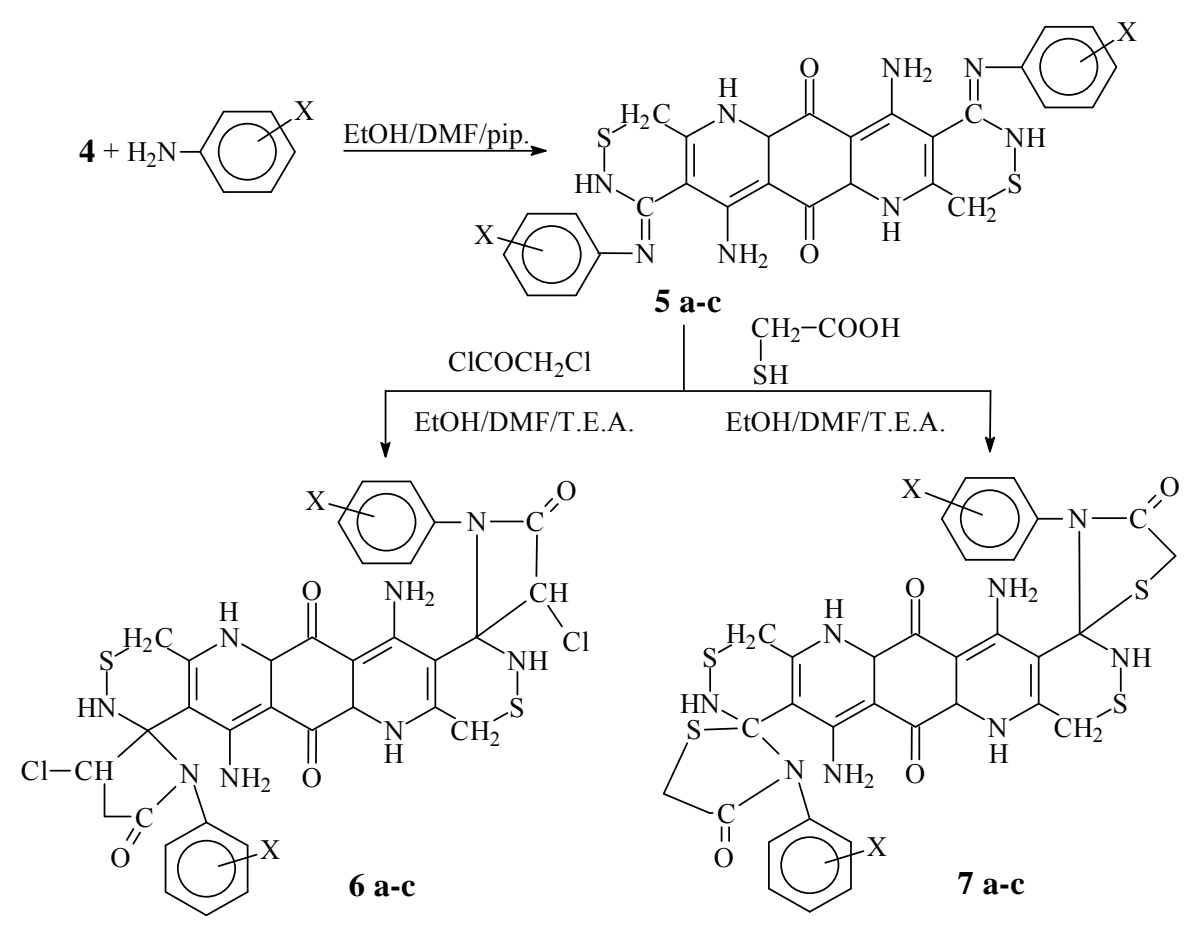

where : $a, X=H ; b, X=O H ; c, X=\mathrm{NO}_{2}$

Scheme 2. Illustrate the formation of compound 5a-c, 6a-c and 7a-c.

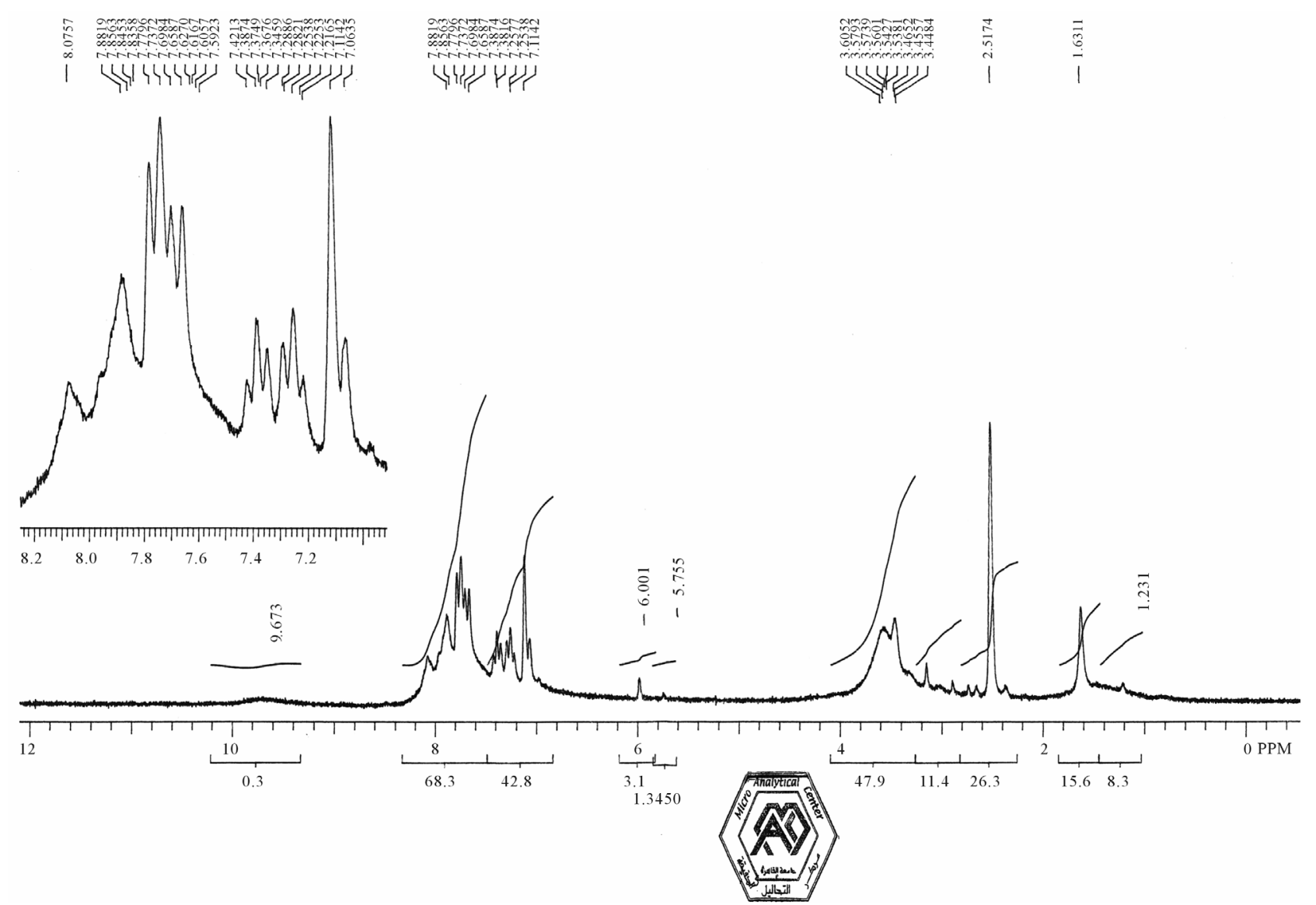

Figure $1 .{ }^{1} \mathrm{HNMR}$ spectra of compound 1 . 


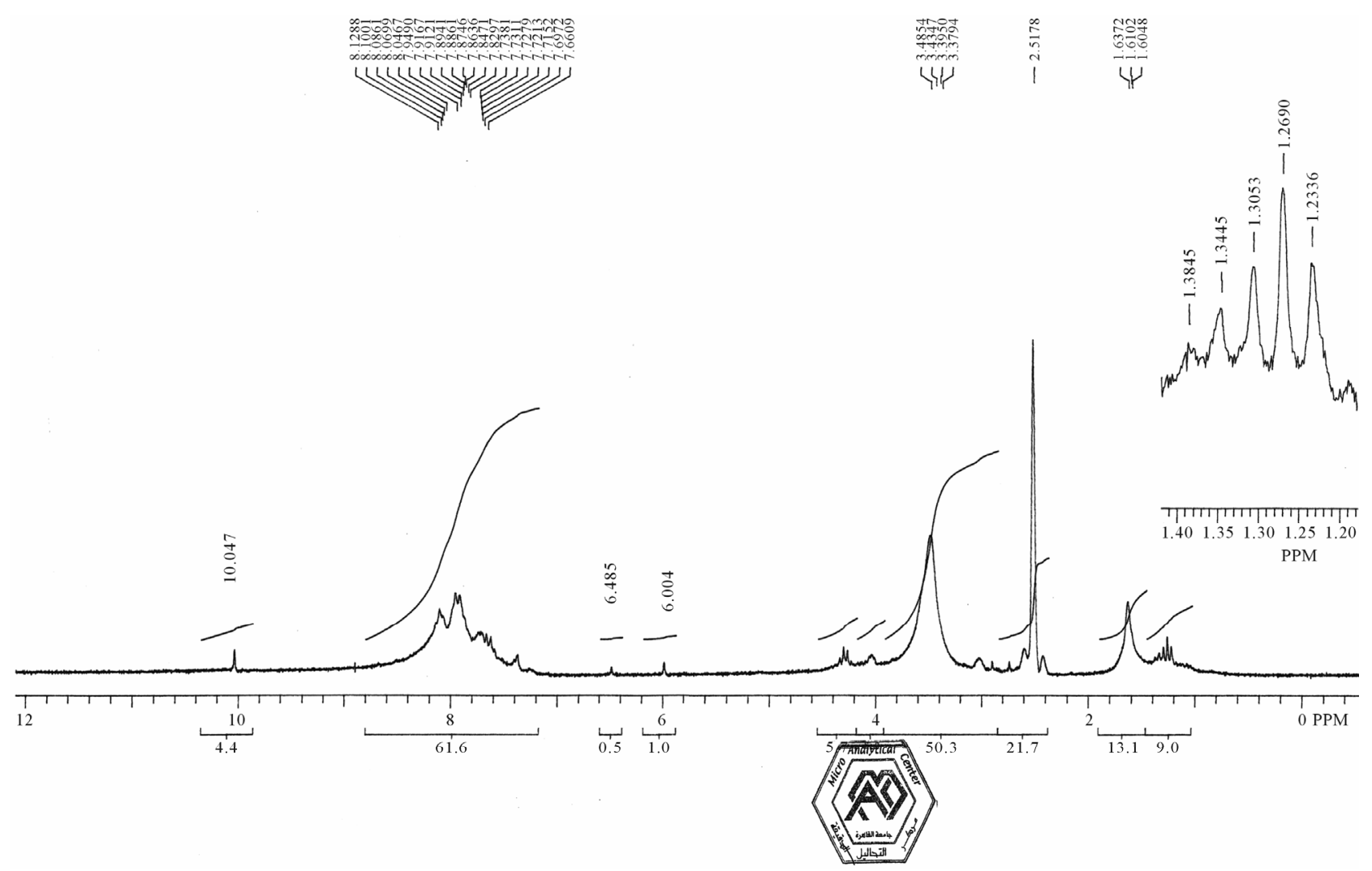

Figure 2. ${ }^{1}$ HNMR spectra of compound 2.
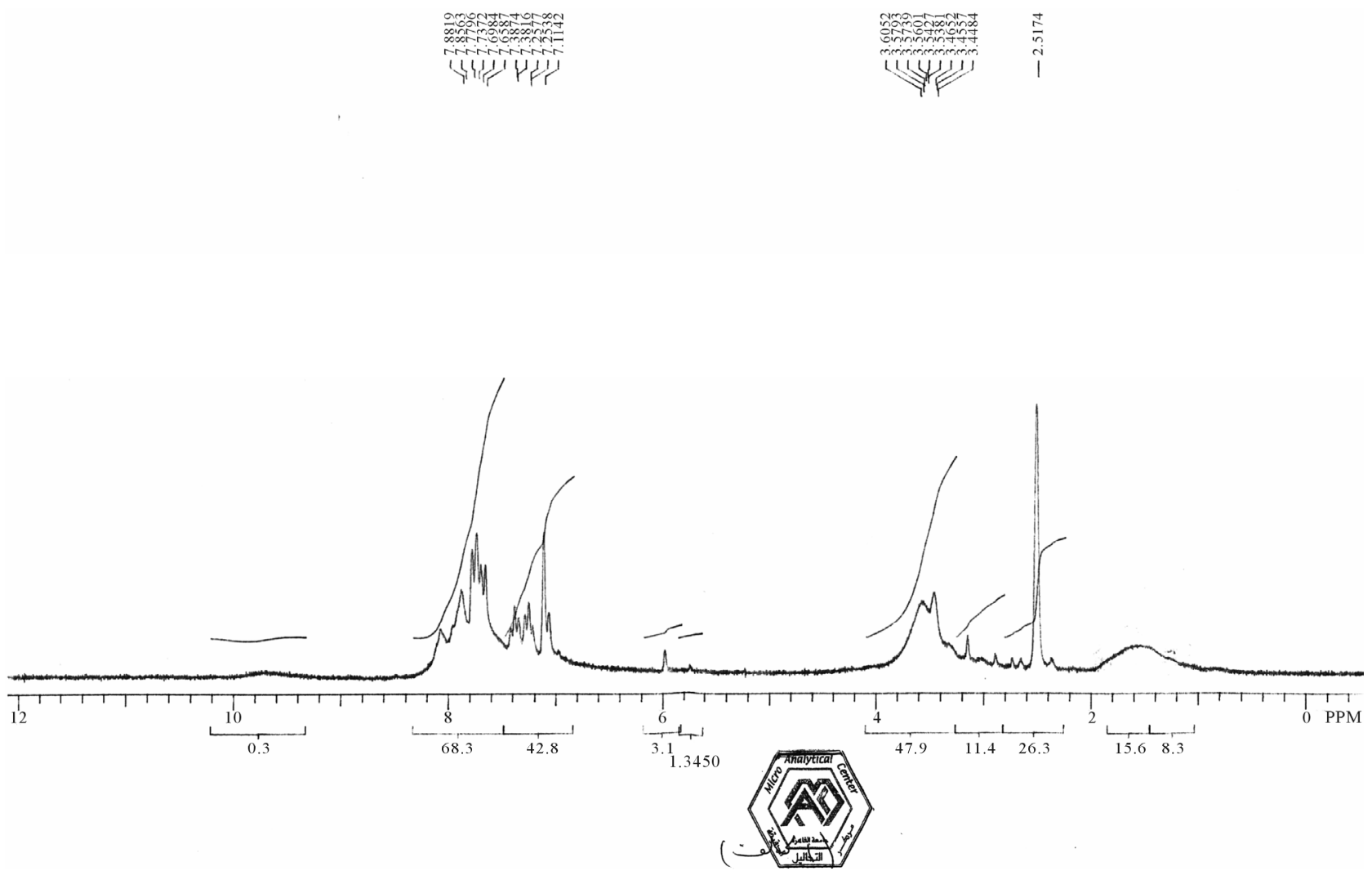

Figure 3. ${ }^{1}$ HNMR spectra of compound 4 . 


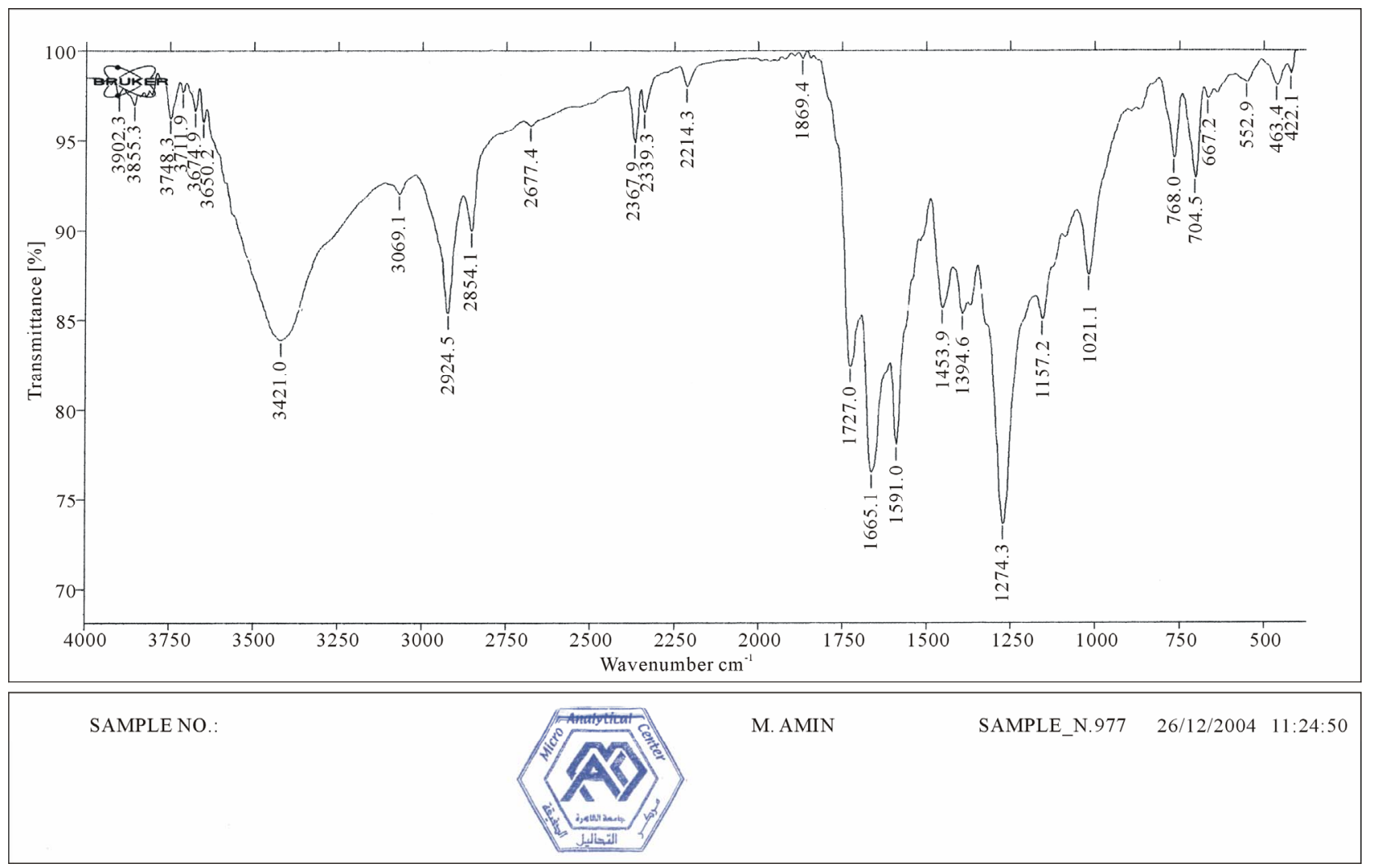

Figure 4. IR spectra of compound 1.

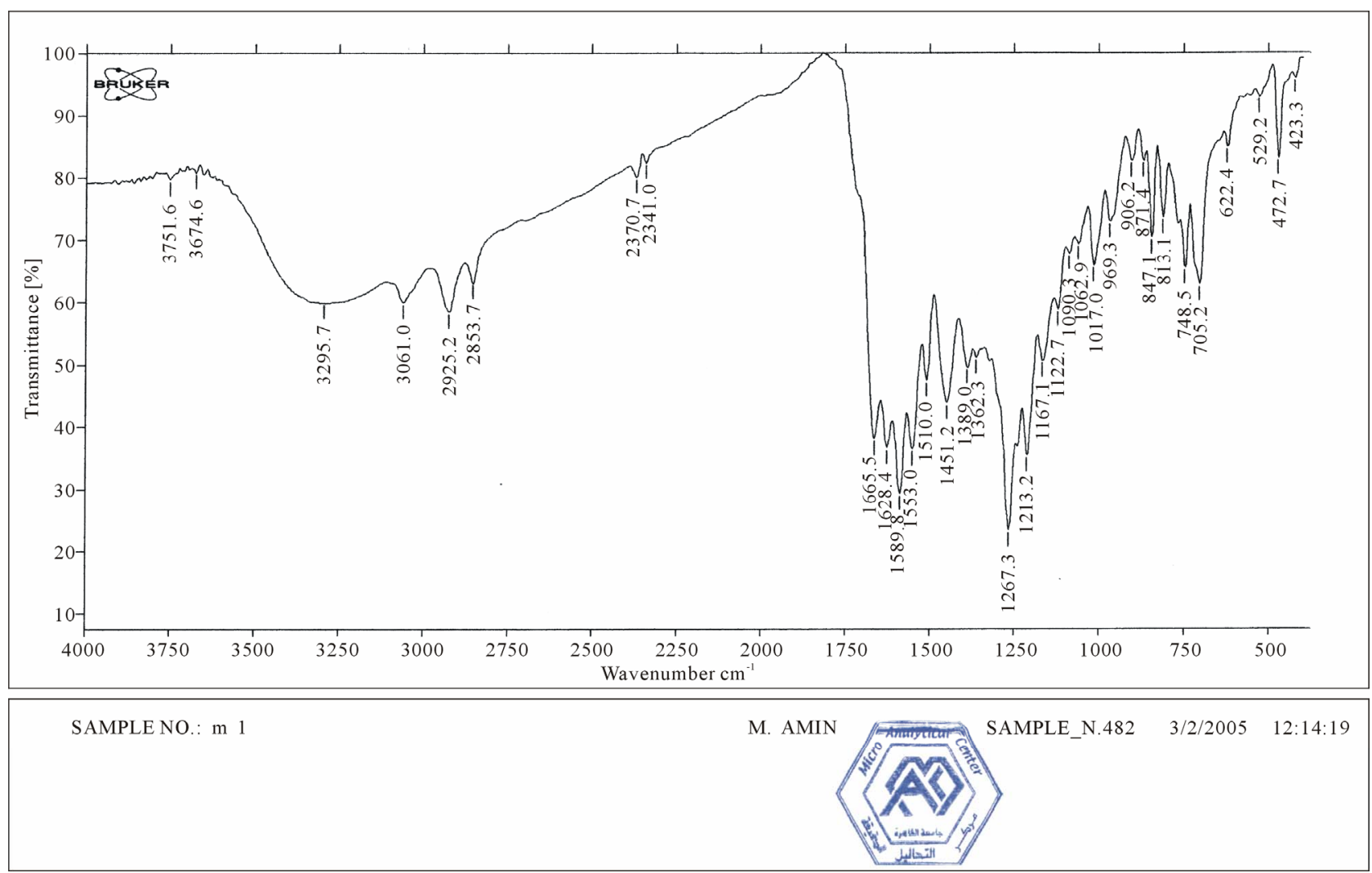

Figure 5. IR spectra of compound 2. 


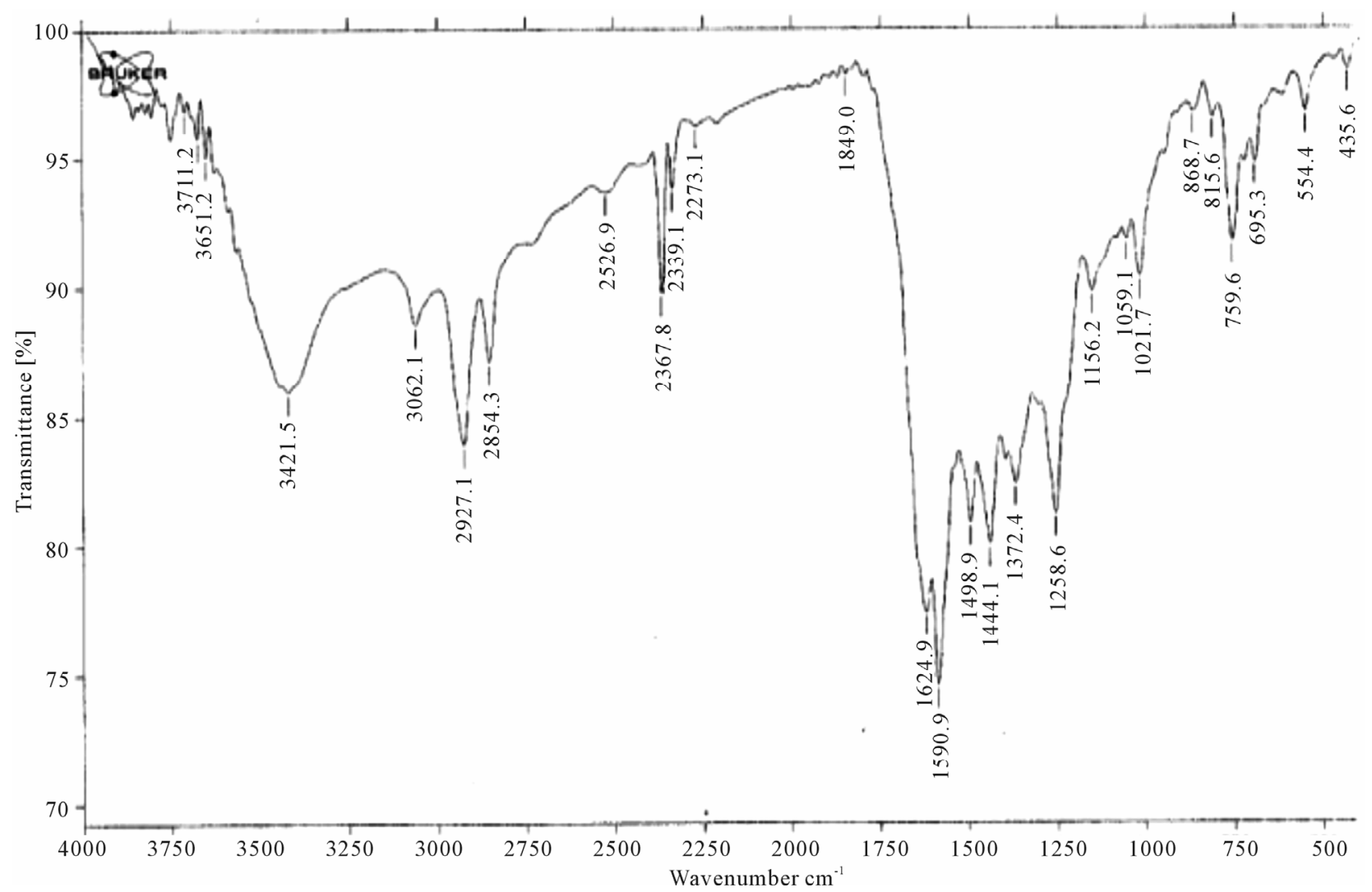

Figure 6. IR spectra of compound 4.

to give new $\beta$-lactams $6 \mathrm{a}-\mathrm{c}$ and new thiazolidinone $7 \mathrm{a}-\mathrm{c}$ The results obtained in this study will be expected useful in medical chemistry.

\section{REFERENCES}

[1] R. Southgate, "The Synthesis of Natural $\beta$-Lactam Antibiotics," Contemporary Organic Synthesis, Vol. 1, No. 6, 1994, pp. 417-431. doi:10.1039/co9940100417

[2] F. Broccolo, G. Carnally, G. Caltabiano, C. E. A. Cocuzza, C. Fortuna, G. Galletti, P. D. Giacomini, G. Musumarra, R. Musumeci and A. Quitavalla, "Design, Synthesis, and Biological Evaluation of 4-Alkyliden-Beta Lactams: New Products with Promising Antibiotic Activity against resIstant Bacteria," Journal of Medicinal Chemistry, Vol. 49, No. 9, 2006, pp. 2804-2811. doi:10.1021/jm0580510

[3] B. Alcaide, P. Almendros and C. Aragoncillo, " $\beta$-Lactams: Versatile Building Blocks for the Stereoselective Synthesis of Non- $\beta$-Lactam Products," Chemical Reviews, Vol. 107, 2007, pp. 4437-4492.

[4] B. Alcaide and P. Almendros, " $\beta$-Lactams as Versatile Intermediates for the Preparation of Heterocycles of Biological Interest," Current Medicinal Chemistry, Vol. 11, No. 14, 2004, pp. 1921-1949. doi:10.2174/0929867043364856

[5] A. R. A. S. Deshmukh, B. M. Bhawal, D. Krishnaswamy, V. V. Govande, B. A. Shinkre and A. Jayanthi, "Azetidin-
2-Ones, Synthon for Biologically Important Compounds," Current Medicinal Chemistry, Vol. 11, No. 14. 2004, pp. 1889-1920. doi:10.2174/0929867043364874

[6] B. Alcaide and P. Almendros, "Selective Bond Cleavage of the $\beta$-Lactam Nucleus: Application in Stereocontrolled Synthesis," Synlett, Vol. 3, 2002, pp. 381-393. doi: $10.1055 / \mathrm{s}-2002-20448$

[7] C. Palomo, J. M. Aizpurua, I. Ganboa and M. Oiarbide, " $\beta$-lactams as Versatile Intermediates in $\alpha$ - and $\beta$-Amino Acid Synthesis," Synlett, Vol. 12, 2001, pp. 1813-1826. doi: $10.1055 / \mathrm{s}-2001-18733$

[8] I. Ojima, "The Organic Chemistry of $\beta$-Lactams," G. I. Georg, Ed., VCH, New York, 1993, pp. 197-255.

[9] I. Ojima, "Recent Advances in the $\beta$-Lactam Synthon Method," Accounts of Chemical Research, Vol. 28, No. 9, 1995, pp. 383-389. doi:10.1021/ar00057a004

[10] M. O'Driscoll, K. Greenhalgh, A. Young, E. Turos, S. Dickey and D. V. Lim, "Studies on the Antifungal Properties of N-Thiolated $\beta$-Lactams," Bioorganic \& Medicinal Chemistry, Vol. 16, No. 16, 2008, pp. 7832-7837. doi:10.1016/j.bmc.2008.06.035

[11] E. Turos, G. S. K. Reddy, K. Greenhalgh, P. Ramaraju, S. C. Abeylath, S. Jang, S. Dickey and D. V. Lim, "Penicillin-Bound Polyacrylate Nanoparticles: Restoring the Activity of $\beta$-Lactam Antibiotics against MRSA," Bioorganic \& Medicinal Chemistry Letters, Vol. 17, No. 12, 2007, pp. 3468-3472. doi:10.1016/j.bmcl.2007.03.077

[12] S. Dugar, N. Yumibe, J. W. Clader, M. Vizziano, K. Huie, 
M. van Heek, D. S. Compton and H. R. Davis Jr., "Metabolism and Structure Activity Data Based Drug Design: Discovery of (-) SCH53079 an Analog of the Potent Cholesterol Absorption Inhibitor (-) SCH48461," Bioorganic \& Medicinal Chemistry Letters, Vol. 6, No. 11, 1996, pp. 1271-1274. doi:10.1016/0960-894X(96)00214-4

[13] W. T. Han, A. K. Trehan, J. J. K. Wright, M. E. Federici, S. M. Seiler and N. A. Meanwell, "Azetidin-2-One Derivatives as Inhibitors of Thrombin," Bioorganic \& $\mathrm{Me}$ dicinal Chemistry, Vol. 3, No. 8, 1995, pp. 1123-1143. doi:10.1016/0968-0896(95)00101-L

[14] A. D. Borthwick, G. Weingarte, T. M. Haley, M. Tomaszewski, W. Wang, Z. Hu, J. Bedard, H. Jin, L. Yuen and T. S. Mansour, "Design and Synthesis of Monocyclic $\beta$ Lactams as Mechanismbased Inhibitors of Human Cytomegalovirus Protease," Bioorganic \& Medicinal Chemistry Letters, Vol. 8, No. 4, 1998, pp. 365-370. doi:10.1016/S0960-894X(98)00032-8

[15] G. Cainelli, P. Galletti, S. Garbisa, D. Giacomini and L.Sartor, "Quintavalla, A. 4-Alkylideneazetidin-2-Ones: Novel Inhibitors of Leukocyte Elastase and Gelatinase," Bioorganic \& Medicinal Chemistry, Vol. 11, No. 24, 2003, pp. 5391-5399. doi:10.1016/j.bmc.2003.09.035

[16] N. E. Zhou, D. Guo, G.Thomas, A. V. N. Reddy, J. Kaleta, E. Purisima, R. Menard, R. G. Micetich and R. Singh, "3-Acylamino-Azetidin-2-One as a Novel Class of Cysteine Proteases Inhibitors," Bioorganic \& Medicinal Chemistry Letters, Vol. 13, No. 1, 2003, pp. 139-141. doi:10.1016/S0960-894X(02)00831-4

[17] A. Kazi, R. Hill, T. E. Long, D. J. Kuhn, E. Turos and Q. P. Dou, "Novel N-Thiolated $\beta$-Lactam Antibiotics Selectively Induce Apoptosis in Human Tumor and Transformed, but Not Normal or Nontransformed, Cells," Biochemical Pharmacology, Vol. 67, No. 2, 2004, pp. 365374. doi:10.1016/j.bcp.2003.09.017

[18] E. Alonso, F. Lopez-Ortiz, C. Del Pozo, E. Peratta, A. Macias and J. Gonzalaz, "Spiro $\beta$-Lactams as $\beta$-Turn Mimetics. Design, Synthesis, and NMR Conformational Analysis," The Journal of Organic Chemistry, Vol. 66, No. 19, 2001, pp. 6333-6338. doi:10.1021/jo015714m

[19] H. Bittermann and P. Gmeiner, "Chirospecific Synthesis of Spirocyclic $\beta$-Lactams and Their Characterization as Potent Type ii $\beta$-Turn Inducing Peptide Mimetics," The Journal of Organic Chemistry, Vol. 71, No. 1, 2006, pp. 97-102. doi:10.1021/jo0517287

[20] E. Alonso, C. Del Pozo and J. Gonzalez, "Synthesis of $\alpha, \alpha$-Disubstituted $\beta$-Amino Esters and Peptide Derivatives," Synlett, Vol. 1, 2002, pp. 69-72. doi:10.1055/s-2002-19326

[21] J. L. Pinder and S. M. Weinreb, "Preliminary Feasibility Studies on Total Synthesis of the Unusual Marine Bryozoan Alkaloids Chartellamide A and B," Tetrahedron Letters, Vol. 44, No. 21, 2003, pp. 4141-4143. doi:10.1016/S0040-4039(03)00876-1

[22] J. W. Skiles and D. McNeil, "Spiro Indolinone BetaLactams, Inhibitors of Poliovirus and Rhinovirus 3c-Proteinases," Tetrahedron Letters, Vol. 31, No. 50, 1990, pp. 7277-7280. doi:10.1016/S0040-4039(00)88543-3
[23] A. Jarrahpour and D. Khalili, "Synthesis of Some Monoand Bis-Spiro- $\beta$-Lactams of Benzylisatin," Tetrahedron Letters, Vol. 48, No. 40, 2007, pp. 7140-7143. doi:10.1016/j.tetlet.2007.07.199

[24] X. Lin and S. M. Weinreb, "Model Studies on Total Synthesis of the Chartellines, Spirocyclic $\beta$-Lactam Alkaloids from a Marine Bryozoan," Tetrahedron Letters, Vol. 42, No. 14, 2001, pp. 2631-2633. doi:10.1016/S0040-4039(01)00270-2

[25] S. Anklam and J. Liebscher, "Synthesis of Optically Active Spiro- $\beta$-Lactams by Cycloadditions to $\alpha$-Alkylidene$\beta$-Lactams," Tetrahedron, Vol. 54, No. 23, 1998, pp. 6369-6384. doi:10.1016/S0040-4020(98)00296-8

[26] B. Alcaide, P. Almendros, T. M. Del Campo, R. Rodríguez-Acebes, "Diversity-Oriented Preparation of Enantiopure Spirocyclic 2-Azetidinones from $\alpha$-Oxo- $\beta$-Lactams through Barbier-Type Reactions Followed by MetalCatalyzed Cyclizations," Advanced Synthesis \& Catalysis, Vol. 349, No. 4-5, 2007, pp. 749-758. doi:10.1002/adsc. 200600502

[27] A. Gareth, C. Jonathan and D. H. Stuart, "Azabicyclic Amino Acids by Stereoselective Dearomatizing Cyclization of the Enolates of N-Nicotinoyl Glycine Derivatives," Organic Letters, Vol. 8, No. 23, 2006, pp. 53255328. doi:10.1021/o1062126s

[28] A. Bhalla, P. Venugopalan and S. S. Bari, "A New Synthetic Approach to Novel Spiro- $\beta$-Lactams," European Journal of Organic Chemistry, Vol. 2006, No. 21, 2006, pp. 4943-4950. doi:10.1002/ejoc. 200600458

[29] A. Zanobini, A. Brandi and A. De Meijere, "A New Three-Component Cascade Reaction to Yield 3-Spirocyclopropanated $\beta$-Lactams," European Journal of Organic Chemistry, Vol. 2006, No. 5, 2006, pp. 1251-1255. doi:10.1002/ejoc. 200500838

[30] A. Zanobini, M. Gensini, J. Magull, D. Vidovic, S. I. Kozhushkov, A. Brandi and A. De Meijere, "A Convenient New Synthesis of 3-Substituted $\beta$-Lactams Formally Derived from 1-(Aminomethyl)cyclopropanecarboxylic acids," European Journal of Organic Chemistry, Vol. 2004, No. 20, 2004, pp. 4158-4166. doi:10.1002/ejoc.200400392

[31] B. Alcaide, P. Almendros and R. Rodríguez-Acebes, "Pd$\mathrm{Cu}$ Bimetallic Catalyzed Domino Cyclization of $\alpha$-Allenols Followed by a Coupling Reaction: New Sequence Leading to Functionalized Spirolactams," Chemistry of the European Journal, Vol. 11, No. 19, 2005, pp. 57085712. doi:10.1002/chem.200500228

[32] A. Bhalla, P. Venugopalan, K. K. Bhasin and S. S. Bari, "Seleno- $\beta$-Lactams: Synthesis of Monocyclic and Spirocyclic Selenoazetidin-2-Ones," Tetrahedron, Vol. 63, No. 15, 2007, pp. 3195-3204. doi:10.1016/j.tet.2007.02.001

[33] C. V. Galliford, J. S. Martenson, C. Stern and K. A. Scheidt, "A Highly Diastereoselective, CatalyticthreeComponent Assemblyreaction for the Synthesis of Spiropyrrolidinyloxindoles," Chemical Communications, Vol. 2007, No. 6, 2007, pp. 631-633. doi:10.1039/b609155e

[34] C. Sun, X. Lin and M. Weinreb, "Explorations on the Total Synthesis of the Unusual Marine Alkaloid Chartelline A," The Journal of Organic Chemistry, Vol. 71, No. 
8, 2006, pp. 3159-3166. doi:10.1021/jo060084f

[35] B. Alcaide, P. Almendros and R. Rodriguez-Acebes, "Efficient Entry to Diversely Functionalized Spirocyclic Oxindoles from Isatins through Carbonyl-Addition/Cyclization Reaction Sequences," The Journal of Organic Chemistry, Vol. 71, No. 6, 2006, pp. 2346-2351. doi:10.1021/jo0525027

[36] G. Cremonesi, P. Dalla Croce and C. La Rosa, "Synthesis of Imidazo[5,1-b]thiazoles or Spiro- $\beta$-Lactams by Reaction of Imines with Mesoionic Compounds or Ketenes Generated from N-Acylthiazolidine-2-carboxylic Acids," Tetrahedron, Vol. 60, No. 1, 2004, pp. 93-97. doi:10.1016/j.tet.2003.10.093

[37] B. Alcaide, P. Almendros, T. M. Del Campo and R. Rodriguez-Acebes, "Metal-Assisted Synthesis of Enantiopure Spirocyclic $\beta$-Lactams from Azetidine-2,3-Diones," Tetrahedron Letters, Vol. 45, No. 34, 2004, pp. 6429-6431. doi:10.1016/j.tetlet.2004.06.130

[38] N. Toshio, K. Shigeo and I. Minoru, "Novel Synthesis of Bromoindolenine with Spiro-Blactam in Chartelline," Synlett, Vol. 2004, 2004, pp. 2025-2027.

[39] O. Arjona, A. G. Csaky, M. C. Murcia and J. Plumet, "The Staudinger Reaction of Imines Derived from 7-Oxanorbornenone: Formation of Spiranic Oxazinone versus $\beta$-Lactam Rings," Tetrahedron Letters, Vol. 43, No. 36, 2002, pp. 6405-6408. doi:10.1016/S0040-4039(02)01375-8

[40] E. Alonso, C. Del Pozo and J. Gonzalez, "Staudinger Reactions of Unsymmetrical Cyclic Ketenes: A Synthetically Useful Approach to Spiro $\beta$-Lactams and Derivatives. Reaction Mechanism and Theoretical Studies," Journal of the Chemical Society, Perkin Transactions, Vol. 1, No. 4, 2002, pp. 571-576. doi:10.1039/b103279h

[41] I. R. Cooper, R. Grigg, W. S. MacLachlan, M. ThorntonPett and V. Sridharane, "3-Component Palladium-Indium
Mediated Diastereoselective Cascade Allylation of Imines with Allenes and Aryl Iodides," Chemical Communications, Vol. 13, 2002, pp. 1372-1373. doi: $10.1039 / \mathrm{b} 202940 \mathrm{e}$

[42] C. Palomo, J. M. Aizpurua, I. Ganboa and M. Oiarbide, "Asymmetric Synthesis of $\beta$-Lactams through the Staudinger Reaction and Their Use as Building Blocks of Natural and Nonnatural Products," Current Medicinal Chemistry, Vol. 11, No. 14, 2004, pp. 1837-1872. doi: 10.2174/0929867043364900

[43] I. Banik, F. F. Becker and B. K. Banik, "Stereoselective Synthesis of $\beta$-Lactams with Polyaromatic Imines: Entry to New and Novel Anticancer Agents," Journal of Medicinal Chemistry, Vol. 46, No. 1, 2003, pp. 12-15. doi:10.1021/jm0255825

[44] B. K. Banik, F. F. Becker and I. Banik, "Synthesis of Anticancer $\beta$-Lactams: Mechanism of Action," Bioorganic \& Medicinal Chemistry, Vol. 12, No. 10, 2004, pp. 2523-2528. doi:10.1016/j.bmc.2004.03.033

[45] F. F. Becker and B. K. Banik, "Polycyclic Aromatic Compounds as Anticancer Agents: Synthesis and Biological Evaluation of Some Chrysene Derivatives," Bioorganic \& Medicinal Chemistry Letters, Vol. 8, No. 20, 1998 , pp. $2877-2880$. doi:10.1016/S0960-894X(98)00520-4

[46] A. K. Khalafallah, R. M. Abdel Aal and N. A. A. Elkanzi, "Synthesis of Some New Fused/Spiro Heterocyclic Compound Incorporating Quinone Compounds," Journal of the Chinese Chemical Society, Vol. 49, 2002, pp. 387696.

[47] N. A. A. Elkanzi, A. K. Khalafallah and M. Younis, "Effect of Iodine on the Antimicrobial Activity of New Spiro and Isolated $\beta$-Lactam Thiazolidinone Derivatives," Phosphorus, Sulfur and Silicon, Vol. 182, 2007, pp. 11631181. 